\title{
Sid New Disease Reports \\ First report of Pepper mild mottle virus infecting chilli pepper in Pakistan
}

\author{
A. Ahmad ${ }^{1}$, A. Tiberini ${ }^{2}$, M. Ashfaq ${ }^{1}$ and L. Tomassoli ${ }^{3}$ \\ ${ }^{1}$ Plant Virology Laboratory, Department of Plant Pathology, PMAS-Arid Agriculture University. Rawalpindi, Pakistan; ${ }^{2}$ \\ Università degli Studi "Mediterranea" di Reggio Calabria, Dipartimento di Agraria, 89122 Feo di Vito, Reggio Calabria, Italy; \\ ${ }^{3}$ Consiglio per la ricerca in agricoltura e l'analisi dell'economia agrari - CREA, Centro di ricerca per la patologia vegetale, \\ Via Carlo Giuseppe Bertero 22, 00156 Rome, Italy
}

*E-mail: adnan_84@outlook.com

Received: 25 Nov 2015. Published: 12 Dec 2015. Keywords: Capsicum annuum, tobamovirus

Chilli pepper (Capsicum апnиum) is an important cash crop in Pakistan which is cultivated on an area of 62,500 ha with an annual yield of 145,100 tonnes (Farooq, 2014). Pepper mild mottle virus (PMMoV) is a singlestranded RNA virus belonging to the genus Tobamovirus, family Virgaviridae (King et al., 2011). The virus possesses a serious threat to pepper cultivation worldwide due to its long-term survival and highly efficient transmission through seeds, plant debris, and on contaminated worker's hands and tools.

During the summers of 2013 and 2014, surveys were done to identify the major viruses infecting chilli crops in the Pothwar region of Pakistan. A total of 25 chilli pepper leaf samples showing symptoms of puckering and yellow or light green mottling were collected from stunted plants from different locations. Total RNA was extracted from these samples using TRIzol $^{\circledR}$ Reagent (Life Technologies, Carlsbad, USA). Six of the 25 samples were positive by one step RT-PCR using PMMoV-specific primers MP/for (5'-TAAAATTGGGCAGAACTCGGAG-3' and 3'UTR/rev (5'-ACGACAACCCTTCGATTTAAGT- ${ }^{\prime}$ ), designed from an alignment of PMMoV sequences. After purification using the Amicon ${ }^{\circledR}$ Ultra kit (EMD Millipore, Billerica, USA) the amplicons were directly sequenced in both directions (BioFab, Rome, Italy). A phylogenetic tree was obtained using the neighbour-joining method based on the Kimura 2-parameter model in MEGA6 (Tamura et al., 2013). The sequences of the $629 \mathrm{bp}$ amplicon from all six isolates, including the complete coat protein gene (474 bp), were identical. The sequence of one isolate (AAR-PK) was submitted to GenBank (Accession No. KT853037). BLASTn analyses showed $>99 \%$ sequence identity of the Pothwar-Pakistan isolate of PMMoV with PMMoV isolates from Asia, including China (KP345899), India (KJ631123) and Japan (KJ631123). Phylogenetic analysis (Fig. 1) supported the grouping of the Pothwar-Pakistan isolate within the pathotype P12 cluster (Caglar et al., 2013; Rialch et al., 2015), although validation of the pathotype would require phenotyping on differential hosts including alleles with $L^{2}$ gene-mediated resistance.

To the best of our knowledge, this is the first report of PMMoV infecting chilli pepper in Pakistan. Therefore, there is a need to strictly control seed quality and to extend surveillance to assess PMMoV incidence in other chilli-growing areas of Pakistan.

\section{References}

Çağlar BK, Fidan H, Elbeaino T, 2013. Detection and molecular characterization of Pepper mild mottle virus from Turkey. Journal of Phytopathology 161, 434-438. http://dx.doi.org/10.1111/jph.12068

Farooq O, 2014. Agriculture. In: Wasti SE, ed. Economic Survey of Pakistan 2013-14. Islamabad, Pakistan: Ministry of Finance, Government of Pakistan, 23-41. Retrieved 25 November 2015 from http://finance.gov.pk/survey_1314.html

Rialch N, Sharma V, Sharma A, Sharma PN, 2015. Characterization and complete nucleotide sequencing of Pepper mild mottle virus infecting bell pepper in India. Phytoparasitica 43, 327-337.

http://dx.doi.org/10.1007/s12600-015-0453-6

King AMQ, Adams MJ, Carstens EB, Lefkowitz EJ, eds, 2012. Virus Taxonomy: Classification and Nomenclature of Viruses. Ninth Report of the International Committee on Taxonomy of Viruses. San Diego, USA: Elsevier Academic Press.

Tamura K, Stecher G, Peterson D, Filipski A, Kumar S, 2013. MEGA6: Molecular Evolutionary Genetics Analysis version 6.0. Molecular Biology and Evolution 30, 2725-2729. http://dx.doi.org/10.1093/molbev/mst197

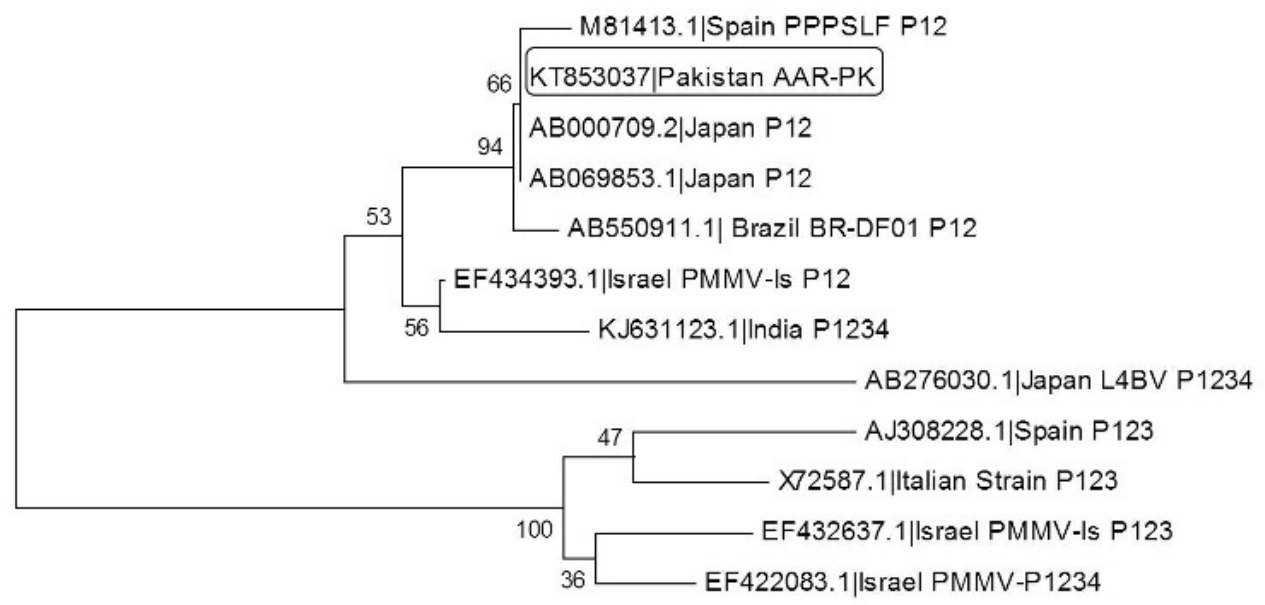

0.005

Figure 1

To cite this report: Ahmad A, Tiberini A, Ashfaq M, Tomassoli L, 2015. First report of Pepper mild mottle virus infecting chilli pepper in Pakistan. New Disease Reports 32, 31. http://dx.doi.org/10.5197/j.2044-0588.2015.032.031

(C) 2015 The Authors

This report was published on-line at www.ndrs.org.uk where high quality versions of the figures can be found. 